\title{
Insights into the subtitling of films from Arabic into Spanish
}

Noha Abdallah Mohamed Moussa

n.a.moussa21@gmail.com

Ain Shams University, Egypt

Miguel Ángel Candel-Mora

mcandel@upv.es

Universitat Politècnica de València, Spain

Mohamed Moussa, N. A., \& Candel-Mora, M. A. (2021). Insights into the subtitling of films from Arabic into Spanish. Language Value, 14(1), 60-84. Universitat Jaume I ePress: Castelló, Spain. http://www.languagevalue.uji.es.

July 2021

DOI: $10.6035 /$ languagev.5822

ISSN 1989-7103

\section{ABSTRACT}

Audiovisual translation studies (AVT) have experienced an exponential growth in the last twenty years, have consolidated proven analysis methodologies, and attracted the interest mainly of Western scholars. It is interesting to investigate whether these methodologies are also applicable to the study of subtitling of films from linguistically and culturally distant cultures such as Egyptian and Spanish. Therefore, the main objective of this work is to verify whether the translation norms proposed in the translation methods for dubbing and subtitling, traditionally based on language combinations with English, are applicable for the specific case of the Arabic-Spanish language combination, based on the analysis of the treatment of the cultural elements present in the audiovisual texts selected for this research. Among the findings, the distinctive features and colloquial character and spontaneity of the original versions are frequently lost.

Keywords: Audiovisual translation; subtitling; translation norm; cultural term. 


\section{INTRODUCTION}

The advent of Audiovisual translation studies (AVT) took place in the academic world in the early 1960s following the publication of the issue of the journal Babel devoted to film translation. Since then, this speciality of translation has become increasingly important. The 21st century marks the beginning of the exponential growth of audiovisual translation, with a progressive shift towards audiovisual media over print media, making audiovisual translation "the most dynamic and fastest developing trend within Translation Studies" (Orero, 2004), and a field of great interest in western academic circles.

On the basis of the linguistic and intercultural distance between the Egyptian and Spanish cultures, this study is approached with the intention of contributing to the existing literature on translation methods for dubbing and subtitling, with a special focus on translation norms. This study arises from the aspiration to deepen into a relatively unexplored field in the variety of audiovisual translation of subtitling in the ArabicSpanish language pair, in particular, in Egyptian films subtitled in Spanish. After a detailed screening of several films, two key films in Egyptian cinematography directed by Youssef Chahine have been selected: Cairo Station (Bāb al-ḥadīd) (1958) and The Earth (Al-'rd) (1969) for their high number of representative samples of potential cultural constraints, and for their importance in both Arab and Egyptian film history.

Since the early 1980s, the study of translation as a cultural rather than simply linguistic phenomenon has been advocated. Especially in the early 1990s, with the cultural perspective on translation known as Cultural turn. According to Hurtado Albir (1994, p. 35), scholars agree in presenting translation not as a process of transcoding from language to language but as a transcultural act (Snell-Hornby); a communicative process that takes place within a social context (Hatim and Mason); an intersystemic act of communication (Toury); or a communicative practice and therefore a type of social behaviour (Hermans).

Translation is not only linguistic, but also textual and socio-cultural, and it is also conditioned by the circumstances that occur at each historical moment (Rabadán, 1991, p. 28). The translation of cultural elements is an essential tool for establishing identities and for facilitating (or hindering) intercultural understanding (Igareda, 2011, p. 14). 
Therefore, the main objective of this work is to verify whether the translation norms studied in the translation methods for dubbing and subtitling, traditionally based on language combinations with English, are applicable to analyse AVT for the specific case of the Arabic-Spanish language combination, based on the analysis of the treatment of the cultural elements present in the audiovisual texts selected for this research. To achieve this, the following specific objectives are proposed: determine a methodological framework for analysing the translation of the cultural elements of the selected corpus, taking as a reference the cultural translation theories and the theoretical review of the four central notions of analysis: constraints, norms and techniques, together with the concept of the translation method; and, identify the translator method used to carry out the interlinguistic transfer for the specific case of Arabic-Spanish, in order to determine the cultural focal points of greatest cultural conflict in this language pair.

From the descriptive studies of translation approach, in the elaboration of the methodology, we have followed Martí Ferriol's model (2006), which is made up of three parameters: constraints, techniques and norms of audiovisual translation.

The study was carried out in three stages:

1. The conceptual stage, in which the theoretical framework and instruments of analysis were determined. A review is carried out of the state of the art of theoretical proposals of a cultural nature, the treatment of cultural elements in Translation Studies, the theories on the three parameters of analysis and the translation method. For each of these three parameters, we review the classification of various proposals made by different Translation Studies scholars, such as the contributions by the School of Manipulation, Toury $(1980,1995)$ and Rabadán (1991), among others, and then by the theories oriented towards AVT: Goris (1993), Ballester (2001), Díaz Cintas (2003), Chaume (2005), Martí Ferriol (2006, 2013) and Rica Peromingo (2016).

2. The methodological stage: based on the contributions reviewed in the previous stage, we propose a taxonomy or model of analysis in accordance with the characteristics of subtitling from Arabic into Spanish, taking as a reference the classification of Martí Ferriol $(2006,2013)$. Both films and their subtitled versions are viewed. This practice facilitates the identification of representative samples from a translatological point of view. 
3. The analytical stage: a qualitative analysis is carried out on the samples extracted from the corpus for subsequent quantitative analysis.

\section{LITERATURE REVIEW}

In this section, we review the context of cinema in Egypt, the literature on subtitling and the current state of subtitling in Egypt, to finally highlight the findings identified in the corpus and present our proposal of classification of translation norms adapted to subtitling from Arabic into Spanish.

\section{II.1. Cinema in Egypt}

Egyptian cinema is the oldest and most influential in the Arab world, considered the paradigm for Arab filmmakers. The beginnings of cinema in Egypt coincide with the rise of cinema in Europe. Due to its enormous film production, Egypt has been considered the 'Hollywood of the Middle East'. The origins of the Egyptian film industry date back to the 1930s, along with the establishment of Studio Misr. Since 1936, Egypt began to participate in international film festivals, which led to its prominent position as a key representative of Arab cinema.

Egypt was the only Arab country that could establish a national film industry during the colonial period. From the first Egyptian film in 1927 to the present day, Egyptian film production has reached almost 3,000 films, representing about three quarters of the total Arab production. The success of the Egyptian film industry is due to several reasons, among them the dynamic and multicultural life in the country and the coexistence of Egyptians with different cultures and nationalities without, at that time, submitting to the colonial authorities. Although the British occupation ended in 1952, resistance to foreign domination and Egyptians' interest in establishing their own identity became more tangible in many fields, especially after the establishment of the Al-Wafd political party in 1918 and the 1919 Revolution. In 1937, the Egyptian government stipulated the abolition of the Capitulations which gave special legal rights to Europeans.

In the 1940s, film production experienced its golden years and Cairo was considered the film capital of the Arab world and the film industry became the second source of wealth 
after cotton production. Samir Farid (2011), one of the leading historians of Egyptian and Arab cinema, notes that the Egyptian film market is one of only three markets in the world where national films get the largest share, thanks to laws that protect national production.

Shafik (1998) adds that the introduction of sound led to a boom in the Egyptian film industry and a profusion of musical films by famous singers such as Mohamed Abdel Wahab and Om Kulzum. This author offers a classification of Egyptian cinema by decades: 1) In the 1940s, genres were mixed; 2) The 1950s and 1960s were marked by melodramatic realism and Hollywood adaptations; 3) The 1970s and 1980s were characterized by social drama criticising the country's social and political situation and the re-emergence of the genres of farce, comedy and early melodrama.

The director of the films studied in this work, Youssef Chahine (1926-2008), is one of the most important personalities in the history of Egyptian and Arab cinema who enjoys the greatest international fame. He directed more than 40 films and documentaries presented at international festivals and shown commercially in Europe and the United States. Throughout his career, he won many awards, such as the Silver Bear at the Berlin Film Festival (1979) and the Special Fiftieth Anniversary Prize at the Cannes Film Festival (1997), among others.

Despite the proximity between Spain and the Arab World due to the long Arab presence in Spain (711-1492), almost eight centuries of scientific and cultural legacy, Arab cinema has a very scarce presence in Spanish commercial cinemas due to several factors such as distribution and the domination of American cinema. Among the Spanish festivals specialising in presenting Arab cinema, rich in its subject matter and artistic level but unknown to many, are the Mostra del Mediterrani in Valencia, the Mostra de Cinema Africà in Barcelona, the Festival Internacional de Cine Euroárabe (Amal) in Santiago de Compostela, the Festival of African cinema of Tarifa (FCAT), the Mostra de Cinema Àrab i Mediterrani in Sant Feliu de Llobregat (Barcelona), and the Festival de Cines del Sur in Granada. In addition to the aforementioned festivals and exhibitions, Spanish spectators can access Arab films through film libraries, the Arab film cycles offered by Casa Árabe, and Martes de Cine, a programme organised by the Fundación Tres Culturas in Seville, 
which aims to raise awareness of the culture of the Middle East and North Africa through cinema as a transmitter of a country's culture.

\section{II.2. Audiovisual translation and subtitling}

For Chaume (2004: 31), audiovisual translation modes are the technical methods used to carry out the linguistic transfer of an audiovisual text from one language to another. Audiovisual texts are characterised by two codes, the visual code which is invariable and the oral or linguistic code which is translated through different modalities. The most prominent and most widely accepted modes of audiovisual translation in the literature are dubbing, subtitling, voice-over and simultaneous interpreting, with a special focus on dubbing and subtitling, which are the most widespread and popular modes.

The most recent and complete classification of subtitling (Díaz Cintas and Remael, 2007) consists of 5 parameters: 1). Linguistic parameters, with the distinction between intralinguistic, interlinguistic and bilingual subtitles; 2). Preparation time available, with two types, online pre-preparation and live or real-time offline subtitling, also known as simultaneous subtitling; 3). Technical parameters, open captioning and closed captioning; 4). Method of subtitle projection: photochemical subtitling, laser subtitling, or, most common today, electronic subtitling; and, 5). Distribution format, such as cinema, television, DVD or Internet.

Since the beginnings of audiovisual translation studies and its modalities, there have been numerous publications on the preference for applying one mode or another, thus constituting a controversial issue among scholars of this discipline. A review of the international panorama of subtitling and dubbing countries shows that, in Western Europe, countries such as Germany, Spain, France and Italy opt for dubbing, while others such as Portugal, the Netherlands, Greece and the Scandinavian countries opt for subtitling. Díaz Cintas (2003) points out that in many cases the various modes of audiovisual translation coexist depending on whether the product is broadcasted on television or cinema, the genre of the programme and the profile of the audience. For example, products aimed at children or older audiences are dubbed because it is easier than reading the subtitles, even in subtitling countries. 
There are several reasons that justify the choice of a particular mode. The economic factor of the country has a lot to do with the chosen mode; many countries opt for subtitling because it is less expensive than dubbing. It is also important to highlight viewers' tastes and habits, as they are accustomed to one mode that is more comfortable than another, and changing these habits would entail many economic risks. From a cultural perspective, the higher the level of unfamiliarity with the source language of the film, the greater the opposition to subtitling by the target audience. At other times, politics may justify the use of dubbing over subtitling, which is seen as a means of preserving the language from linguistic invasion. Four of the countries that follow dubbing policy had dictatorial regimes: Germany, Spain, France and Italy. Agost (1999) points out that the origin of the division between dubbing and subtitling countries was the economic and cultural supremacy of the USA after the Second World War and the increase of its audiovisual products, which made fascist or dictatorial regimes such as Germany, Spain, France and Italy choose dubbing as an instrument of censorship.

The advocates of subtitling are in favour of this method for several reasons: a) It is cheaper than dubbing; b) It makes it possible to enjoy the foreign language and the original voices of the actors; c) It has a didactic value, since in recent years subtitles have become a powerful tool in the teaching of foreign languages.

On the other hand, supporters of dubbing argue that subtitles contaminate the image and distract the attention of viewers who have to take in both the image and the subtitles at the same time, which leads the translator to omit or discard a large part of the original dialogue. Another criticism is that cinema is an entertaining activity, therefore, the effort exerted by the viewer to read and perceive the subtitles results in reducing this sense of entertainment.

\section{i) Audiovisual translation in Egypt}

In Egypt, subtitling was considered the best option to protect the local industry from competition, in addition to being a less costly procedure than dubbing, as it involves fewer participants and requires fewer stages. Subtitling in Egypt is attributed to the effort and hard work of Anis Ebaid who dominated the audiovisual scene in Egypt for almost forty years in the period between 1944 and 1989. 
The emerging subtitling industry worked closely with the censors. No sexual language, no blasphemous references to the Almighty, prophets or revealed books were allowed, which made the language used in subtitles seem like "genre sui generis" (Gamal, 2008, p. 3). When translating these taboo language elements into Arabic, subtitlers tend to use "certain lexical items and syntax that was odd and stilted" (Gamal, 2008, p. 4). This issue became more noticeable with the advent of television in 1960 when a new era of audiovisual translation began and the Egyptian Radio and Television Union developed its own centre.

Until 1990, most AVT in Egypt was limited to subtitling. Although subtitling is considered the preferred mode, some attempts at dubbing have been made but were unsuccessful because the films are dubbed in classical Arabic (fușhā) which produces the strange effect of hearing familiar voices while the action and images on screen show a totally different culture.

The digital revolution of the mid-1990s and the commercialisation of the Internet made AVT a growing industry. By the late 1990s, the number of satellite channels had reached over a hundred and most of them were broadcasting constantly. Until 2002, the translation of foreign films into Arabic was dominant and very little Egyptian cinema was translated into other languages. The situation changed with the emerging DVD industry producing a steady number of Egyptian films subtitled in English and French.

With regard to the training of audiovisual translators in the Arab world, Gamal (2007) indicates that the increase in the number of companies offering audiovisual translation services, particularly in Syria, Lebanon, Jordan, Egypt and Dubai, as well as the increase in broadcasting hours and the unprecedented demand for audiovisual translators has not been supported by an increase in training institutions. In the entire Arab world there are only two academic institutions offering academic training in audiovisual translation: one in Cairo (The American University) and the other in Beirut (Balamand University). Audiovisual translation in the Arab World remains beyond the reach of translation departments at a time when there is a clear need to embrace the concept, localise the discipline and invest in the training of specialists in Arabic AVT studies. 
Over the last two decades, Mexican, Korean and Turkish dramas invaded the Arab World through dubbing into the Syrian dialect and the Egyptian vernacular understood by most Arab countries due to the large production of Egyptian films, TV series and songs.

Unlike subtitling, the proliferation of satellite channels gave a major boost to dubbing. By the mid-1990s, a new trend was emerging in the dubbing of foreign television drama in Lebanon and Egypt. This phenomenon known as "Mexican drama" originated in Mexico, Brazil and Spain and was dubbed into Modern Standard Arabic (MSA). With Mexican drama, dubbing was a contributing factor to the externalisation of the film material that was not helped by the predominantly female actresses with white complexions, blonde hair and different body language, westernised lifestyles and more liberal attitudes towards love, sex and material values.

In 2008, Egyptian viewers were able to watch on pay-TV the new wave of dubbed TV dramas that spread throughout the Arab world "The Turkish Drama". With the second wave of dubbed TV dramas, some important changes can be observed. Essentially, dubbing took place in Syria and in the vernacular of the Syrian dialect. Turkish drama dubbed in Arabic has been labelled as a new shift that has brought life to Arabiclanguage drama production, especially the Syrian dialect, and has brought foreign romance to Arabic television in a way that is linguistically acceptable and culturally appropriate.

However, the change also brought challenges to Egyptian drama, which has always been held in high esteem in Arab countries. The Egyptian dialect, long perceived as the lingua franca in the Arab world, faced an important competitor, as the Syrian dialect, coupled with superior foreign production, and posed a challenge that many believe will shake Egyptian drama out of its complacency.

The unprecedented success of the dubbed Turkish drama is attributed to three main factors: Syrian Arabic was used instead of MSA, which helped to bring the work closer to the viewer, and, secondly, the Turkish culture is close to the Arab culture, particularly in its social customs, cultural values, nuances and feelings. And finally, dubbing was done professionally, with great care to the details of translation, language details, articulation and timing. 
The feedback from the Turkish drama demonstrated that dubbing has been successful in domesticating foreign work and, for the first time, seems to have gained recognition and acceptance as a viable method of translating television dramas in the Arab culture.

\section{II.3. Subtitling norms as parameters of translation analysis}

In audiovisual translation studies (Ferriol, 2006, 2013), the key notions for defining and describing the translation method are based on translation techniques, translation constraints and translation norms, the latter as the object of this study.

Translation techniques serve as analytical tools for the description and comparison of translations and allow us to identify the equivalences chosen by the translator for textual micro-units as well as to obtain data on the methodological option used (Hurtado Albir, 2014, p. 257).

Among the different proposals of translation techniques is Molina and Hurtado Albir's compilation (2001, p. 114-116): adaptation, linguistic amplification, amplification, calque, compensation, linguistic compression, discursive creation, description, established equivalent, generalisation, modulation, particularisation, borrowing, reduction, substitution, literal translation, transposition and variation.

Martí Ferriol's $(2006,2013)$ proposal, specifically adapted to audiovisual translation, is based on Molina and Hurtado Albir (2001), with some modifications such as adding two more techniques: word-for-word translation and one-for-one translation; distinguishing between omission and reduction to establish a gradation in the degree of intervention of the translator (Martí Ferriol, 2013, p. 118); and, eliminating the compensation technique due to the difficulty of identifying and locating it, especially in the variety of audiovisual translation.

Its validity is related to several issues such as: the context, the purpose of the translation, audience expectations, the genre of the text, the modality of the translation (written translation, sight translation, etc.), the type of translation (technical translation, literary translation, etc.), and so on.

In his handbook on translation, Ghazala (1995: 195-209) adopts a practical rather than

a theoretical approach in dealing with the problems generated by English-Arabic 
interlanguage transfer, and proposes a list of sixteen procedures or techniques, which are described below:

1. Cultural equivalent: finding an equivalent in the target language $(T L)$ that can be used in the same context providing the same meaning as the source language (SL). For example, translate The British Council by البريطاني الثقافي المركز

2. Cultural correspondence: using a term in the TL that could have exactly and literally the same term in the SL. For example, "Security Council" as الأمن مجلس, "to hit two birds with one stone" as بحجر عصفورين يضرب.

3. Accepted standard translation: using a term or expression that is already commonly accepted in everyday usage, especially terms related to technology, the Internet, etc. For example, "spare parts" as السيارات غيار قطع

4. Naturalization: adapting a word from the SL to the morphology and pronunciation of the TL. For example, "democracy" as ديمقراطية , and “Hercules" as هرقل.

5. General sense: replacing a SL term with a clarification of its meaning because there is no equivalent term in the TL. For example, "paddy fields" as الأرز حقول

6. Transcription/transference: transliterating the word as it is pronounced in the SL. For example, "cricket" as يكتكر.

7. Literal translation: translating the meaning of expressions literally. For example, “The White House" as الأبيض البيت.

8. Translation couplet: combining two translation techniques.

For example, “Pentagon” as البنتاجون ) الأمريكية الدفاع وزارة) (transcription and paraphrase).

9. Translation triplet: similar to the previous technique, but in this case three techniques are used. For example, “jeans jacket” as أمريكي جينز سترة (literal translation, transcription and classifier). 
10. Classifier: introducing a classifier that explains or clarifies the cultural component when there is a risk that the text will be incomprehensible. For example, "sake" as الساكي شراب, "rock" as الروك موسيقى.

11. Neutralization: functional/descriptive equivalent: this technique is a "kind of deculturalization" of the cultural term of the SL, removing its cultural feature and using a neutral term. For example, “Kremlin” as الروسي الرئاسي القصر.

12. Componential analysis: adding clarifying details not included in the SL. For example, “continental breakfast": أوروبي فطور: )توست( محمص وخبز وقهوة شاي.

13. Paraphrase: provide a succinct explanation to clarify the meaning of the term in question. For example, "ham" as الخنزير فخذ شر ائح.

14. Translation label: this is a non-standardized, provisional translation of a neologism, which is enclosed in quotation marks or brackets to indicate its transitional nature. For example: “love virus” ] الحاسب تخريب فيروس ]الحب فيروس.

15. Deletion: omission of an element present in the SL from the TL.

For example: “AIDS" المناعة نقصinstead of المكتسبة المناعة نقص مرض.

16. Gloss/glossary, notes and footnotes: providing an explanation of a vague or misleading word or expression by means of a footnote or glossary at the end of the text. For example: “ploughman's lunch" الجعة ومشروب ومخلات وجبن خبز من مؤلف بسيط غداء:الفلاح غداء

Translation problems are "the difficulties (linguistic, extra-linguistic, etc.) of an objective nature that the translator may encounter when carrying out a translation task" (Hurtado Albir, 2014: 286). According to Hurtado Albir, the notion of problem is of vital importance in translation didactics and evaluation, as it "guides the elaboration of learning objectives as well as the comparison of the translation with the original text" (2014, p. 279).

Despite its great importance, only a few authors address the issue of translation problems. Lorscher (1991) acknowledges that "the absence of empirical approaches and the strong speculative tendency" (quoted in Hurtado Albir, 2014, p. 280) led to the scarcity of analysis of this translatological issue. 
There is no unanimous consensus among translatologists about its definition or its classification, as Presas (1996) points out that "there is a lack of a definition of the concept of translation problem with a theoretical basis and systematisation" (quoted in Hurtado Albir, 2014, p. 280).

Based on the proposal of Nord (1991) and the PACTE group (2011), Hurtado Albir (2014, p. 288) proposes a typology of translation problems composed of five basic categories:

1. Linguistic problems: include problems related to the linguistic code, especially at the lexical and morphosyntactic levels.

2. Textual problems: refer to problems related to issues of coherence, thematic progression, cohesion, textual typologies (genre conventions) and style.

3. Extra-linguistic problems: these are problems which refer to thematic, encyclopaedic and cultural issues. They are related to cultural differences.

4. Intentionality problems: related to difficulties in capturing information from the original text (intention, intertextuality, speech acts, presuppositions, implicatures).

5. Pragmatic problems: arise from the translation project, the characteristics of the receiver and the context in which the translation is carried out.

With regard to translation norms, the object of this study, the work by Martí Ferriol $(2006,2013)$, based on the contributions of Goris and Ballester, studies the subtitled and dubbed versions of five films belonging to the genre "American independent auteur cinema" released between 2001 and 2004, focusing on the theoretical concept of the translation method and on the three parameters (norm, technique and constraint) used for its identification. For the translation phase, Martí Ferriol (2013, pp. 71-72) proposes six types of norms:

1. Linguistic standardisation: neutralisation (levelling) of the non-standard features of the different dialectal (including social) varieties of the source language, of the idiolects and of all linguistic registers.

2. Naturalisation: adaptation (graphic substitution, voice-over or subtitling) of graphic signs (labels, titles, etc.); adaptation of pronunciation (proper names 
and place names are pronounced according to the phonetic rules of the target language); the familiarising treatment of socio-cultural references; and, especially, respect for visual synchrony (phonetic, kinesic and isochrony synchrony), which is clearly conditioned by planning (Chaume, 2003a, p. 251): for certain types of shots, it is more important that the translation conforms to the movements of the actors on screen than to what they actually say in the source language.

3. Explicitation: of vague or equivocal expressions, connectors or logical connections. It also consists of the addition of internal references to reinforce the homogeneity of the structure of the story, and the textual explicitness of the images.

4. Linguistic fidelity: maintenance of the morphology, syntax or grammatical constructions (especially simple ones) of the original text.

5. Euphemisation: alteration of the ethical sign of some element of the original text, softening it.

6. Dysphemisation: alteration of the ethical sign of some element of the original text, hardening it.

\section{METHODOLOGY}

In order to verify whether the translation norms considered in AVT methods, traditionally based on language combinations with English, are adequate for the specific case of the Arabic-Spanish language combination, we start from one of the most common translation problems in the literature: the treatment of the cultural elements present in the audiovisual texts selected for this research. For our corpus, we have selected two Egyptian films directed by Youssef Chahine: Cairo Station (Bāb al-ḥadīd, 1958) and The Earth (Al-'rd, 1969).

The work was structured in three phases: in the first phase, the films and their subtitled versions were viewed with the aim of detecting the most representative cultural elements or those that call the attention from a translatological point of view for the 
creation of an aligned bilingual corpus, built from the transcriptions of both Arabic films that have been manually transcribed and their Spanish versions already prepared in .srt format with the time codes in hours, minutes, seconds and milliseconds. The corpus of Spanish subtitled versions was extracted from the Opensubtitles.org platform, whose database includes more than three million subtitles in more than 60 languages. In the second phase, a database record template was designed for the extraction of cultural elements and the subsequent qualitative analysis of the selected samples.

Table 1. Database record template for qualitative analysis.

\begin{tabular}{|l|l|}
\hline Sample & $\begin{array}{l}\text { To facilitate tracking, a code has been assigned to identify the name of the film } \\
\text { abbreviated in letters: EC (Estación Central) Cairo Station and LT (La tierra) The } \\
\text { Earth, together with the number of the subtitle in sequential order, according to } \\
\text { its appearance in the subtitled version. }\end{array}$ \\
\hline TCR & $\begin{array}{l}\text { (Time Code Reading): time of the film where the sample appears on the screen, } \\
\text { shown in hours, minutes and seconds. }\end{array}$ \\
\hline OV & $\begin{array}{l}\text { Original Arabic version. We display the selected subtitle or subtitles of the film, } \\
\text { highlighting the expression or term studied in bold. In some cases, we mention, } \\
\text { in the same sample, all the recurrences of a given term, explaining its meaning } \\
\text { in each of them. }\end{array}$ \\
\hline SV & $\begin{array}{l}\text { Spanish subtitled version. } \\
\text { used by the subtitled version for the transfer of the sample in question. }\end{array}$ \\
\hline Norm & \begin{tabular}{l} 
Technique(s) of the subtitled version for the transfer of the studied sample. \\
\hline Technique
\end{tabular} \\
\hline
\end{tabular}

Table 2. Example of a completed database record.

\begin{tabular}{|l|l|}
\hline Sample code & EC66 \\
\hline TCR & $00: 15: 34$ \\
\hline OV & Hay que luchar si queréis ganarse la vida \\
\hline SV & Explicitación \\
\hline Norm & Descripción \\
\hline Technique & \\
\hline
\end{tabular}

In the third phase, a preliminary classification into seven categories of the cultural elements identified with the potential to be considered a translation problem was carried out according to their content: sayings and proverbs, general lexical issues, interjections and onomatopoeias, fixed expressions, text-image relationship, socio- 
cultural references and religious references. After this initial work, in the fourth phase, the cultural elements of the original versions and their corresponding translations were identified and extracted manually by the authors of this work and included in their corresponding category in the database. Finally, after an exhaustive analysis, in the last phase, the norms and techniques used by the subtitled versions for the transfer of cultural elements into the target language were identified.

\section{RESULTS AND DISCUSSION}

The audiovisual language of the films under study is colloquial, characterised by a profusion of idioms, expressions and idiomatic expressions, among other features. Due to the cultural distance between the cultures in question and the non-existence of an equivalent in the target language, together with the spatio-temporal limitation of subtitling, translators often resort to move away from the literal translation. Using the descriptive approach based on the three parameters of audiovisual translation analysis, norms, techniques and constraints, a total of 194 samples containing 229 cultural elements (CE) were collected during the cultural term identification phase.

Table 3 shows the classification of the cultural elements analysed that were used to determine the type of translation norm used and to achieve the aim of this work of verifying whether the existing theoretical frameworks, based primarily on language combinations with English, are applicable for the translation from Arabic into Spanish.

As shown in Table 3, the film Cairo Station has a higher occurrence of constraints than The Earth. The constraints with the highest presence in the corpus are fixed expressions and socio-cultural references. They are followed by religious references and general lexical questions, and finally, sayings and proverbs, interjections and onomatopoeias, and the text-image relationship, which present almost the same number of frequencies in our corpus.

Table 3. Classification of the cultural elements analysed.

\begin{tabular}{|l|l|l|l|l|}
\hline & $\begin{array}{l}\text { Cairo } \\
\text { Station }\end{array}$ & The Earth & $\begin{array}{l}\text { Total } \\
\text { samples }\end{array}$ & $\begin{array}{l}\text { Total } \\
\text { Cultural } \\
\text { Elements }\end{array}$ \\
\hline
\end{tabular}




\begin{tabular}{|l|l|l|l|l|}
\hline Sayings and proverbs & 9 & 2 & 11 & 11 \\
\hline General lexical issues & 16 & 9 & 25 & 27 \\
\hline Interjections and onomatopoeias & 4 & 7 & 11 & 13 \\
\hline Fixed expressions & 39 & 19 & 58 & 63 \\
\hline Text-image relationship & 7 & 3 & 10 & 10 \\
\hline Socio-cultural references & 32 & 23 & 55 & 77 \\
\hline Religious references & 10 & 14 & 24 & 28 \\
\hline Total & 117 & 77 & 194 & 229 \\
\hline
\end{tabular}

Both formulas of address and vocative and interjective expressions play an essential role in the characterisation of interlocutors and their relations with each other. Their transposition into another language raises complex socio-cultural translation problems, since they differ not only from one language to another but also from one social group to another within the same language. This problem is even worse in the case of conversational discourse such as audiovisual texts.

Several factors influence the use of forms of address and therefore come into play when translating these problematic expressions: the interpersonal relationship (the distance or proximity between speakers), the hierarchical relationship (difference in age, social class, level of education, etc.), the difference between diatopic varieties (e.g. between city and countryside), diachronic differences, etc.

We see an abundant use of curses and insults in the subtitles of the films, in which the characters show their anger against those who have dedicated themselves to making their lives miserable. Such insults are seen as restitution for a justice that will not come by any other means. Cursing appears in different ways, but most frequently in formulas containing the name of God, a word that was not always preserved in the subtitled versions.

The fact that the religions of the source and target cultures are so different entails that Islamic vocabulary, prayer expressions and Islamic precepts pose cultural pitfalls for translators. Due to the lexical specificity of religious vocabulary and the target audience's lack of Arabic culture referents, there is a greater tendency towards omission, adaptation and discursive creation that reformulates, on certain occasions, 
the original utterance. The use of these techniques generates a more secularised subtitled text, losing the religious imprint of the original text.

In the translation of sayings and proverbs, even in the few cases in which there is one in the $T T$ that provides the same meaning as the original, the subtitled version does not use it, opting for the norm of reformulation associated, normally, with the discursive creation technique that presents a high frequency in this constraint.

Continuing with the quantitative analysis, in terms of the proposed translation norms identified in each film, Table 4 shows a summary of the main findings.

Table 4. Quantitative analysis of the norms in the corpus.

\begin{tabular}{|l|l|l|l|}
\hline Norm & Cairo Station & The Earth & Total \\
\hline Linguistic standardisation & 6 & 7 & 13 \\
\hline Naturalisation & 8 & 14 & 22 \\
\hline Explicitation & 31 & 30 & 61 \\
\hline Linguistic fidelity & 6 & 3 & 9 \\
\hline Euphemisation & 2 & 2 & 4 \\
\hline Dysphemisation & 2 & 1 & 3 \\
\hline Implicitation & 57 & 25 & 82 \\
\hline Reformulation & 38 & 23 & 61 \\
\hline Total & 150 & 105 & 255 \\
\hline
\end{tabular}

As shown in Table 4, the most frequently used norms in our corpus are implicitation and explicitation, which were not included in Martí Ferriol's proposal $(2006,2013)$ based on the subtitling of American independent cinema, but have been necessary for the Arabic to Spanish translator method. The next most frequently used norms are explicitation, reformulation, and naturalisation respectively. The least frequently used norms are: linguistic standardisation and linguistic fidelity. As for euphemisation and dysphemisation, they are applied in very few cases.

According to the data in the tables above, we conclude that the translation method adopted by the subtitled versions is the interpretative-communicative method focused 
on the form of the target message, with a tendency and preference to offer an acceptable translation towards the target language and culture.

In the Arabic culture, formulas of address denoting kinship are frequently used for nonfamily members such as خالتي، أبا، عم، ابني، بنتي (aunt, father, uncle, son and daughter). In most cases, the subtitled version applies the omission technique which leads to the loss of the cultural load of the original. Other formulae do not have an equivalent or analogous term in the TL such as pilgrim حاج (haj/hajj) which was translated by "you" as there is no equivalent in the TL that conveys or reproduces its exact meaning, and the other formula شيخ (sheij) transferred by the SV as "Sheikh", although it does not correspond to its social usage.

Martí Ferriol's (2006) proposal includes six norms: linguistic standardisation, naturalisation, explicitation, linguistic fidelity, euphemisation and dysphemisation; however, we considered it necessary to add two more norms for this study because these norms are the most frequently used to transfer fixed expressions, religious references and interjections and onomatopoeias, the most common translation problems in the case of Arabic-Spanish AVT (see Table 4):

1. Implicitation: elimination of elements considered redundant and/or unimportant, justified or unjustified reduction or suppression of a cultural or linguistic element of the original text. It is opposed to the norm of explicitation. Some examples include the following:

Table 5. Examples of implicitation.

\begin{tabular}{|c|c|c|}
\hline Original arabic version & Spanish subtitle & Observation \\
\hline مش موجود بيصلي العصر في جامع السلطان حسن ، & $\begin{array}{l}\text { Ha salido a } \\
\text { rezar. }\end{array}$ & $\begin{array}{l}\text { Reference to name } \\
\text { and time of prayer is } \\
\text { not specified. }\end{array}$ \\
\hline استغفر الله العظيم بارب دا حر من جهنم، أعوذ بالله، ربنا يلطف & $\begin{array}{l}\text { Hoy hace un } \\
\text { calor infernal. }\end{array}$ & $\begin{array}{l}\text { Reference to religious } \\
\text { cultural elements } \\
\text { removed. }\end{array}$ \\
\hline
\end{tabular}




\begin{tabular}{|l|lr|l|}
\hline & Que nadie & Reference to political \\
& toque el agua & representative \\
& después de los & removed. \\
& $5 \quad$ días & \\
& ¿comprendido? & \\
\hline
\end{tabular}

2. Reformulation: modifying the original message to reduce the number of characters, to conform more closely to the form and/or grammatical rules of the target language or due to the lack of an equivalent term in the target language.

Table 6. Examples of reformulation.

\begin{tabular}{|c|c|c|c|}
\hline Original arabic version & $\begin{array}{l}\text { Spanish } \\
\text { subtitle }\end{array}$ & Observation & \\
\hline إلاهي يهديك & $\begin{array}{l}\text { No seas } \\
\text { pesado. }\end{array}$ & $\begin{array}{l}\text { Religious } \\
\text { removed } \\
\text { reformulated. }\end{array}$ & $\begin{array}{r}\text { expression } \\
\text { and }\end{array}$ \\
\hline ربنا يتمم بخير بس شد حيلك انت & $\begin{array}{l}\text { Es lo mejor. Sé } \\
\text { fuerte. }\end{array}$ & $\begin{array}{l}\text { Religious } \\
\text { removed } \\
\text { reformulated. }\end{array}$ & $\begin{array}{r}\text { expression } \\
\text { and }\end{array}$ \\
\hline هو احنا لحقنا! هما راكبهم عفريت دول ولا ايه & $\begin{array}{l}\text { ¿Los policías? } \\
\text { ¿Ya? }\end{array}$ & $\begin{array}{l}\text { Idiomatic } \\
\text { reformulated. }\end{array}$ & expression \\
\hline
\end{tabular}

In view of the above, the norms we propose for the model of our analysis are: linguistic standardisation, naturalisation, explicitation, linguistic fidelity, euphemisation, dysphemisation, implicitation and reformulation.

Among the translation norms that seem to be associated with the general lexical issues is explicitation that is achieved with the techniques of particularisation and description. 
The subtitled versions choose to offer more specific expressions in order to convey what is meant by the original version.

With regards to interjections and onomatopoeias, the subtitled versions apply, in most cases, implicitation which is always associated throughout the corpus with omission, except in two cases with compression into other categories of constraints.

On the other hand, as far as fixed expressions are concerned the predominant norm is explicitation followed by reformulation and implicitation respectively, together with the techniques that correspond to these norms: description, particularisation, discursive creation and omission.

Explicitation has been identified as the predominant norm for the constraint of Textimage relationship in which the subtitled versions tend to make explicit what is seen in the picture using more precise words.

Both socio-cultural references and religious references show a higher frequency of occurrence of the norm of implicitation.

\section{CONCLUSIONS}

This work is framed within the descriptive studies of translation. The approach of this paper is mainly based on Martí Ferriol's model (2006). For the analysis of the corpus, we have adapted Martí Ferriol's model to the problems that arise in the specific case of subtitling in the Arabic-Spanish language combination by adapting and adding criteria that have been considered relevant and thus propose a model of analysis adapted to this language combination.

The main objective of this study was to verify whether the existing typologies of translation strategies, traditionally based on language combinations with English, are applicable to the analysis of AVT for the specific case of the Arabic-Spanish language combination, based on the analysis of the treatment of the cultural expressions present in the audiovisual texts selected for this research.

In general, the translation criterion adopted by subtitled versions, where there is no existing and recognisable Spanish equivalent that fulfils the same function as the 
original, is to reformulate, omit or paraphrase the content or meaning of the original statement in order to avoid forced phrasing and, at the same time, to achieve the acceptance of the target receiver. However, it does not always carry the same phatic function and expressive force as the original, and the distinctive features of the original versions are lost in the process of linguistic transfer, as in cases of softening or loss of the tone of threat, contempt and irony. In other cases, there exists a change of register where the text is endowed with a degree of formality that diverges substantially from the original, which entails, therefore, a loss of the colloquial character and spontaneity of the original.

The audiovisual language of the films under study is colloquial in nature, characterised by a profusion of idioms and idiomatic expressions, among other features. Due to the cultural distance between the cultures in question and the non-existence of an equivalent in the target language together with the spatial-temporal limitation, translators resort, on most occasions, to departing from literalism.

Forms of address and vocative and interjective expressions play an essential role in the characterisation of interlocutors and their relations with each other. Therefore, their transfer into another language raises complex socio-cultural translation issues, since they differ not only from one language to another but also from one social group to another within the same language.

\section{REFERENCES}

Agost, R. (1999). Traducción y doblaje: palabras, voces e imágenes. Ariel Practicum.

Cerezo Merchán, B. (2012). La didáctica de la traducción audiovisual en España: un estudio de caso empírico-descriptivo [PhD dissertation, Universitat Jaume I]. Universitat Jaume I.

Chaume, F. (2004). Cine y traducción. Cátedra

Chaume, F. (2013). Panorámica de la investigación en traducción para el doblaje. Trans: Revista de Traductología, 17, 13-34.

Díaz Cintas, J. (2001). La traducción audiovisual: el subtitulado. Salamanca: Almar. 
Díaz Cintas, J. (2003). Teoría y práctica de la subtitulación: inglés - español. Ariel.

Díaz Cintas, J., \& Remael, A. (2007). Audiovisual translation: subtitling. St. Jerome.

Duro, M. (Coord.). (2001). La traducción para el doblaje y la subtitulación. Cátedra.

Elena, A. (1999). Los cines periféricos: África, Oriente Medio, India. Paidós.

Elena, A. (2007) (Ed.). Youssef Chahine: el fuego y la palabra. Berenice.

Estación Central, Bāb al-hadīd. Subtitles available in: https://www.opensubtitles.org/en/subtitles/5457671/cairo-station-es

Farid, S. (2007). Youssef Chahine: una historia egipcia. In A. Elena (Ed.) Youssef Chahine: el fuego y la palabra (pp.13-39). Córdoba: Berenice.

Gamal, M. (2007). Audiovisual Translation in the Arab World: A Changing Scene. Translation Watch Quarterly, 3(2). Retrieved from: https://www.researchgate.net/publication/263846928_Audiovisual_Translatio n_in_the_Arab_World_A_Changing_Scene

Gamal, M. (2008). Egypt's audiovisual translation scene. Arab Media and Society, 5. Retrieved from: https://www.academia.edu/7450964/Egypts_audiovisual_translation_scene

Gamal, M. (2009). Foreign movies in Egypt: subtitling, dubbing and adaptation. In A. Goldstein \& B. Golubovic (Eds.). Foreign Language Movies-Dubbing vs subtitling. Verlag Dr. Kovac. Retrieved https://www.researchgate.net/publication/263848514_Foreign_movies_in_Egy pt_subtitling_dubbing_and_adaptation/stats\#fullTextFileContent

Ghazala, H. (2008). Translation as problems and solutions. A Textbook for University Students and Trainee translators.Dar El-IIm lilmalayin. (Original work published 1995).

Gottlieb, H. (1994). Subtitling: Diagonal translation. Perspectives: Studies in Translatology, 2(1), 101-121.

Hart, M. (1994). Subtítulos o doblaje: ¿Cuál cumple mejor con el trasvase cultural? In F. Eguíluz, R. Merino, V. Olsen \& E. Pajares (Eds.) Trasvases Culturales, literatura, 
cine y traducción (pp. 261-268). Facultad de Filología, Departamento de Filología Inglesa y Alemana.

Hurtado Albir, A. (Ed.) (1994). Estudis sobre traducció. Servei de Publicacions de la Universitat Jaume I.

Hurtado Albir, A. \& Molina, L. (2002). Translation Techniques Revisited: A Dynamic and Functionalist Approach. Meta: Translators' Journal, 47(4), 498-512.

Hurtado Albir, A. (2014). Traducción y Traductología: Introducción a la Traductología (7th ed.). Cátedra.

Igareda, P. (2011). Categorización temática del análisis cultural: una propuesta para la traducción. Íkala, revista de lenguaje y cultura, 16(27), 11-32.

Ivarsson, J. (1992). Subtitling for the media: a handbook of an art. Transedit.

La tierra, Al-'rd. Subtitles available in: https://www.opensubtitles.org/en/subtitles/4645746/al-ard-es

Maluf, R. (2005). A potential untapped? Why dubbing has not caught on in the Arab world. Transnational broadcasting studies, 15. Retrieved from: https://www.arabmediasociety.com/a-potential-untapped-why-dubbing-hasnot-caught-on-in-the-arab-world/

Martí Ferriol, J. L. (2006). Estudio empírico y descriptivo del método de traducción para doblaje y subtitulación [PhD dissertation, Universitat Jaume I]. Universitat Jaume I.

Martí Ferriol, J. L. (2013). El método de traducción: doblaje y subtitulación frente a frente. Publicacions de la Universitat Jaume I.

Martínez Álvarez, J. (1990): Las interjecciones. Logroño: Consejería de Educación, Cultura y Deportes del Gobierno de La Rioja.

Moussa, N. (2020). Análisis traductológico de los términos culturales en la subtitulación árabe - español [PhD dissertation, Universitat Politècnica de València]. Universitat Politècnica de València.

Orero, P. (Ed.) (2004). Topics in audiovisual translation. John Benjamins. 
Rabadán, R. (1991). Equivalencia y traducción: problemática de la equivalencia translémica inglés-español. Universidad de León.

Rica Peromingo, J.P. (2016). Aspectos lingüísticos y técnicos de la traducción audiovisual (TAV). Peter Lang.

Shafik, V. (1998). Arab cinema: history and cultural identity. American University in Cairo Press.

Received: 25 March 2021

Accepted: 5 July 2021 